\title{
EVALUASI ISI BUKU TEKS PELAJARAN SEJARAH PADA MASA ORDE BARU
}

\author{
Hieronymus Purwanta \\ FKIP Universitas Sanata Darma (email: psukamiskin@yahoo.co.id)
}

\begin{abstract}
Abstrak: Evaluasi Isi Buku Teks Pelajaran Sejarah pada Masa Orde Baru. Penelitian ini bertujuan untuk mjengevaluasi isi buku teks sejarah untuk sekolah menengah pada masa Order Baru. Penelitian ini merupakan penelitian kualitatif, dengan fokus pada analisis isi buku teks sejarah. Analisis dan evaluasi dilakukan dengan menggunakan kriteria Sartono dalam menulis sejarah nasional. Temuan penelitian menunjukkan bahwa kualitas buku teks sejarah sudah berkembang tetapi masih perlu perbaikan dalam hal pendekatan, kesamaan, dan integrasi nasional.
\end{abstract}

Kata Kunci: evaluasi, pelajaran sejarah, buku teks, kesamaan, integrasi nasional

\begin{abstract}
An Evaluation of The History Textbooks in The New Order Era. This study aimed to evaluate the content of history textbooks for high schools in the New Order era. The research method used was qualitative, focusing on the content analysis of history textbooks. The analysis and evaluation used Sartono's criteria of writing the national history. The findings showed that the quality of history textbooks had already developed, but it needed improvement in approach, equity and national integration.
\end{abstract}

Keywords: evaluation, history textbooks, equity, national integration

\section{PENDAHULUAN}

Dewasa ini, kedudukan buku teks menjadi semakin sentral dalam proses belajar-mengajar karena guru merasa sulit dan berat untuk mengembangkan sendiri materi pelajaran yang diampu, entah karena alasan waktu yang terbatas ataupun tekanan eksternal. Ansary dan Babaii (2002:2) secara detail menjelaskan unsur-unsur pendukung penggunaan buku teks sebagai berikut. Pertama, buku teks merupakan kerangka kerja yang mengatur dan menjadwalkan waktu kegiatan program pengajar- an. Kedua, di mata siswa, tidak ada buku teks berarti tidak ada tujuan. Ketiga, tanpa buku teks, siswa mengira bahwa mereka tidak ditangani secara serius. Keempat, dalam banyak situasi, buku teks dapat berperan sebagai silabus. Kelima, buku teks menyediakan teks pengajaran dan tugas pembelajaran yang siap pakai. Keenam, buku teks merupakan cara yang paling mudah untuk menyediakan bahan pembelajaran. Ketujuh, siswa tidak mempunyai fokus yang jelas tanpa adanya buku teks dan ketergantungan pada guru menjadi 
tinggi. Kedelapan, bagi guru baru yang kurang berpengalaman, buku teks berarti keamanan, petunjuk, dan bantuan.

mengingat kedudukan buku teks yang penting dalam proses belajar mengajar, pada tahun 2005 Departemen Pendidikan Nasionalmengeluarkan Peraturan Menteri Pendidikan Nasional (Permendiknas) No. 11 Tahun 2005 tentang Buku Teks Pelajaran. Pada pasal 3 ayat 1 diatur bahwa buku teks pelajaran untuk setiap mata pelajaran yang digunakan pada satuan pendidikan dasar dan menengah dipilih dari buku-buku teks pelajaran yang telah ditetapkan oleh menteri berdasarkan rekomendasi penilaian kelayakan dari Badan Standar Nasional Pendidikan (BSNP).

BSNP menetapkan empat kriteria utama, yaitu materi, penyajian, bahasa dan keterbacaan, serta grafika. Pada bidang materi pengkajian, kelayakan meliputi kekhususan materi, keakuratan dan kemutakhiran; penyajian informasi yang tidak bias, kesesuaian kosa kata, struktur kalimat, panjang paragraf dan tingkat kemenarikan uraian dengan kognisi siswa; pencantuman rujukan yang digunakan; kesesuaian dan keakuratan ilustrasi, peta, tabel dan grafik dengan teks; kesesuaian materi dengan kurikulum; serta keseimbangan penyebaran materi, baik yang berkenaan dengan pengembangan makna dan pemahaman, pemecahan masalah, pengembangan proses, latihan dan praktik, tes keterampilan maupun pemahaman.

Penilaian aspek penyajian meliputi tujuan pembelajaran, keteraturan urutan dalam penguraian, kemenarikan minatdan perhatian siswa, kemudahan dipahami, keaktifan siswa, hubungan ba- han, serta latihan dan soal. Penilaian aspek bahasa dan keterbacaan meliputi kemudahan membaca (berhubungan dengan bentuk tulisan atau tipografi, ukuran huruf, dan lebar spasi) yang berkaitan dengan aspek grafika; kemenarikan (berhubungan dengan minat pembaca, kepadatan ide bacaan, dan penilaian keindahan gaya tulisan) yang berkaitan dengan aspek penyajian materi; serta kesesuaian (berhubungan dengan kata dan kalimat, panjang-pendek, frekuensi, bangun kalimat, dan susunan paragraf) yang berkaitan dengan bahasa dan keterbacaan. Pada bagian grafika, aspek yang dinilai adalah hal-hal yang berkenaan dengan fisik buku, antara lain: ukuran buku, jenis kertas, cetakan, ukuran huruf, warna, dan ilustrasi.

Ketentuan BSNPberlaku untukbuku teks semua mata pelajaran sehingga kriterianya bersifat elementer. Khusus untuk buku teks pelajaran sejarah, kriteria yang ditentukan oleh BSNP kurang memadai karena tidak mampu mencermati isi di dalamnya. Salah satu alat untuk mengkaji isi buku teks dikemukakan oleh Abdullah dan Surjomihardjo (1985:27-29) yang mengategorisasikan model penulisan sejarah menjadi tiga jenis, yaitu sejarah ideologis, pewarisan, dan akademik. Dari ketiga jenis penulisan sejarah, kiranya sangat sulit untuk secara tegas memilih salah satu sebagai model penulisan buku teks pelajaran sejarah. Buku teks di satu sisi harus mampu menjadi media pewaris, tetapi di sisi lain harus dapat dipertanggungjawabkan secara akademik. Sartono Kartodirdjo (Mulyana dan Darmiasti, 2009:5) memberikan rambu-rambu un- 
tuk penulisan sejarah nasional, yaitu sebagai berikut.

- Mengungkapkan "sejarah daridalam" di mana bangsa Indonesia sendiri memegang peranan pokok.

- Menguraikan faktor atau kekuatan yang memengaruhinya, baik ekonomi, sosial maupun politik, ataupun kultural.

- Mengungkapkan aktivitas pelbagai golongan masyarakat, tidak hanya bangsawan atau ksatria, tetapi juga dari kaum ulama atau petani serta golongan-golongan lainnya.

- Menyusun sejarah Indonesia sebagai suatu sintese, di mana digambarkan proses yang menunjukkan perkembangan ke arah kesatuan geopolitik seperti yang kita hadapi dewasa ini, maka prinsip integrasi perlu dipergunakan untuk mengukur seberapa jauh integrasi itu dalam masa-masa tertentu telah.

Pada rambu tentang mengungkapkan "sejarah dari dalam", Kartodirdjo bermaksud mengembangkan sejarah yang otonom (autonomous history) sebagai solusi kontroversi antara sejarah kolonial dan sejarah nasional (Ileto, 2002). Salah satu unsur sejarah otonom adalah kesadaran akan terdapatnya perbedaan etnik. Nagazumi (1968:219) berpendapat bahwa "only studies carried out by Asians could be regarded as Asia-centric. This he rejected as meaningless since, if it were true, no non-Asians could expect to study Asia" atau hanya kajian yang dilakukan oleh orang Asia yang dapat dinilai sebagai Asia-sentris. Dari perspektif ini, sejarah Indonesia hanya dapat diteliti dengan representatif oleh sejarawan Indonesia. Sejarah Indonesia yang direkonstruksi oleh sejarawan Barat kurang bermakna karena tidak dapat sepenuhnya memahami kebudayaan Indonesia dan pandangan dunianya yang terrepresentasi pada fenomena historis. Kajian Indonesia yang dilakukan oleh Barat dicurigai akan tidak jauh berbeda dengan pandangan kaum Orientalis yang menggambarkan Timur sebagai "were not like "us" and didn't appreciate "our" values" (Said, 1977: xvi).

Kriteria Kartodirdjo nomor (a) dan (b) terkait dengan pendekatan yang dipilih oleh sejarawan Indonesia untuk merekonstruksi sejarah masyarakatnya. Di pihak lain, dari kriteria (c) yang dibuat Kartodirdjo, yaitu aktivitas pelbagai golongan masyarakat, dapat diambil pemahamanbahwa penulisan buku teks pelajaran sejarah harus memperhatikan keberimbangan. Sebagai bangsa yang bhineka, buku teks sejarah Indonesia perlu mewadahi fenomena historis dari perspektif golongan, baik berupa kelas sosial, suku, agama, ras, maupun wilayah sehingga komposisinya dalam buku teks pelajaran sejarah relatif berimbang. Pandangan Kartodirjo tersebut sesuai dengan pendapat Asvi Warman Adam yang menyatakan bahwa sejarah nasional Indonesia sudah seharusnya menggambarkan berbagai etnik dan kekuatan yang ada di Indonesia (Purwanto dan Adam, 2005).

Pada kriteria (d), Kartodirdjo menyebutkan bahwa sejarah Indonesia disusun sebagai suatu sintesis, yaitu integrasi geopolitik nasional Indonesia. Dari sudut pandang ini, pemilihan peristiwa dan perspektif yang terpintal dalam uraian sejarah nasional sudah seharusnya bersifat teleologis atau me- 
nuju satu titik, yaitu integrasi nasional. Dalam konteks ini, teleologis dimaksudkan sebagai usaha menempatkan realitas historis kontemporer menjadi tujuan dari gerak sejarah masa sebelumnya. Dengan kata lain, berdirinya Negara Kesatuan Republik Indonesia pada tahun 1945 dipahami sebagai tujuan dari dinamika historis masyarakat periode-periode sebelumnya. Di pihak lain, penguatan dan pengembangan $\mathrm{Ne}$ gara Kesatuan Republik Indonesia dipahami sebagai tujuan dari dinamika historis periode-periode setelah tahun 1945.

Dengan mempertimbangkan berbagai kriteria yang dapat digunakan untuk mengevaluasi isi buku teks pelajaran sejarah, pada penelitian ini digunakan kriteria yang diajukan oleh Kartodirdjo. Kartodirdjo mengajukan pendekatan, keberagaman, dan integrasi nasional sebagai kriteria, permasalahan penelitian dapat dirumuskan sebagai berikut. (1) Bagaimana isi buku teks pelajaran sejarah SMA ditinjau dari perspektif pendekatan? (2) Bagaimana isi buku teks pelajaran sejarah SMA ditinjau dari perspektif keberagaman? (3) Bagaimana isi buku teks pelajaran sejarah SMA ditinjau dari perspektif integrasi nasional?

Penelitian ini menempatkan buku teks mata pelajaran sejarah SMA Jurusan IPS yang digunakan dalam pembelajaran pada masa Orde Baru sebagai subjek kajian. Karena selama masa Orde Baru terjadi tiga kali pergantian kurikulum, yaitu 1975, 1984 dan 1994, maka subjek penelitian adalah buku teks mata pelajaran sejarah yang digunakan dalam pembelajaran ketiga kurikulum tersebut. Untuk masing-masing kurikulum dipilih tiga buku sehingga secara keseluruhan subjek penelitian berjumlah sembilan buku teks. Agar lebih fokus, penelitian ini mengkaji uraian buku teks tentang sejarah pergerakan nasional (1908-1945).

Penelitian ini merupakan penelitian kualitatif dengan menggunakan metode analisis isi. Untuk memperoleh kajian mendalam terhadap masing-masing kriteria, analisis dilakukan terhadap pendekatan, keberagaman, dan integrasi nasional. Analisis terhadap aspek pendekatan dilakukan dengan meneliti model rekonstruksi sejarah digunakan oleh setiap pengarang buku teks. Ankersmit (1987) menjelaskan bahwa dalam ilmu sejarah, terdapat tiga pendekatan, yaitu deskriptif naratif, hermeneutika, dan covering law model. Setelah dilakukan kategorisasi, selanjutnya dievaluasi dengan menggunakan kemampuan pendekatan yang dipilih pengarang dalam mengungkapkan "sejarah dari dalam".

Analisis terhadap aspek keberagaman dilakukan dengan meneliti kekayaan ragam golongan dan kekuatan dalam masyarakat yang diuraikan oleh setiap pengarang buku teks ketika membahas fenomena historis. Keberagaman yang dapat diuraikan oleh pengarang antara lain dari perspektif wilayah, usia, gender, profesi, etnik, agama, ras, dan adat istiadat. Analisis dilakukan tidak hanya pada jumlah perspektif keberagaman yang dibahas oleh pengarang buku teks, tetapi juga kedalaman pembahasannya. Semakin banyak perspektif golongan yang dibahas dan uraiannya juga representatif, berarti semakin baik 
kategori kualitas keberagaman yang diberikan oleh pengarang.

Analisis terhadap aspek integrasi nasional dilakukan dengan meneliti kekayaan uraian pengarang buku teks tentang fenomena historis yang mencerminkan kebersatuan dan berkembangnya solidaritas antarkelompok kekuatan dan golongan dalam masyarakat. Fenomena historis itu dapat berupa terjalinnya kerjasama sementara, selamanya maupun fusi antarkelompok kekuatan dan golongan. Semakin banyak fenomena historis yang merepresentasikan integrasi nasional dibahas secara mendalam, berarti semakin baik kategori kualitas integrasi nasional yang diberikan oleh pengarang

\section{ISI BUKU TEKS}

\section{Pendekatan}

Dari tiga buku yang diteliti pada Kurikulum 1975, dua buku yang menggunakan pendekatan narratif adalah Siswoyo, S.W., 1979, Sejarah Untuk SMA, jilid 1 dan Idris, Z.H., dkk, 1979, Sejarah Untuk SMA. Di pihak lain, buku yang menggunakan pendekatan struktural adalah Nugroho Notosusanto, dkk., 1981, Sejarah Nasional Indonesia Untuk $S M A$, jilid 3 yang juga dikenal sebagai buku paket. Pada buku Siswoyo, penggunaan pendekatan naratif tampak antara lain pada uraian yang menekankan pada proses terjadinya peristiwa sejarah. Di pihak lain, uraian tentang penyebab atau latar belakang hanya dilakukan dengan singkat. Ketika membahas pergerakan nasional Indonesia, Siswoyo menguraikan latar belakang kemunculannya sebagai berikut.

\begin{abstract}
"Sebab-sebab terjadinya Kebangkitan Nasional Indonesia dapat dibedakan atas faktor dalam negeri dan faktor luar negeri. Faktor-faktor dalam negeri yang menimbulkan Kebangkitan Nasional antara lain adalah: (a) Belanda terlalu memeras bangsa Indonesia dengan menjadikan semacam sapi perahan bagi kehidupan bangsa Belanda. Ujudnya antara lain berupa batig saldo; (b) Perbedaan hidup yang menyolok antara bangsa Belanda yang berkuasa dengan bangsa Indonesia yang dikuasai. Perbedaan ini nyata dalam pemberian gaji, kedudukan sosial, tingkat kemakmuran dan sebagainya...(g) Bahasa Melayu yang merupakan bahasa kesatuan makin menyadarkan bahwa bangsa Indonesia berasal dari satu bangsa. Anggapan bahwa bahasa Melayu merupakan bahasa yang rendah tingkatnya (sebagai bahasa pasaran), menjadikan bangsa Indonesia makin kuat rasa solidaritasnya (Siswoyo, 1979, jilid 1: 151-152)."
\end{abstract}

Kutipan di atas memperlihatkan bahwa latar belakang fenomena historis kurang diperhatikan, yang diuraikan hanya dalam bentuk point-poin yang berisi satu atau dua kalimat.

Di pihak lain, perhatian yang besar diberikan oleh Siswoyo ketika menguraikan bagaimana suatu fenomena historis terjadi.

"Pada mulanya Boedi Oetomo hanya bergerak dalam bidang sosialbudaya saja. Misalnya, mendirikan sekolah-sekolah yang juga dinamakan Boedi Oetomo (BO) dan berusaha memelihara dan memajukan kebudayaan Jawa. Anggotanya terbatas untuk suku Jawa dan dari lingkungan atasan saja, belum merakyat. Dalam tahun pertama Boedi Oetomo 
mendapat kemajuan pesat, pada akhir tahun 1909 telah mempunyai 40 cabang dengan jumlah anggota sebanyak 10.000 orang. Setelah itu sedikit mundur karena saingan perkumpulan lain yang lingkungannya tidak terbatas di Jawa dan anggotanya mencakup masyarakat luas."

"Sejak tahun 1915, Boedi Oetomo bergerak dalam lapangan politik. Yang mendorong adalah berkecamuknya Perang Dunia I (1914-1918) dan Boedi Oetomo berpendapat bahwa bangsa Indonesia perlu ikut serta dalam pembelaan negara. Setelah Volksraad dibentuk (1918), Boedi Oetomo mempunyai wakil di dalamnya. Pandangannya adalah bahwa sebaiknya pemerintahan dibentuk atas azas kebangsaan dan mengakui kedudukan agama sama (Siswoyo, 1979, jilid 1: 153)."

Pola yang sama juga digunakan oleh Idris. Hal itu dapat disimak ketika Idris menjelaskan latar belakang kemunculan pergerakan nasional. Bahkan, ketika menguraikan proses terjadinya fenomena historis, Idris jauh lebih singkat dari yang dilakukan oleh Siswoyo. Akibatnya, uraiannya lebih menyerupai kronik daripada penggambaran detil suatu peristiwa sejarah. Hal itu dapat disimak pada narasinya tentang organisasi-organisasi pergerakan politik sebagai berikut.

(1) Serikat Dagang Islam (SDI) didirikan pada tahun 1911 oleh Haji Samanhudi di Surakarta. (2) Tahun 1912 SDI diperluas dan menjelma menjadi partai politik yaitu Serikat Islam (S.I.), dipimpin oleh HOS Cokroaminoto, H. Agus Salim, Suryopranoto, dan lain-lain. (3) Tahun 1912 berdiri Partai Kebangsaan Hindia (National
Indische Party = NIP) yang dipimpin oleh dr. Cipto Mangunkusumo, Ki Hajar Dewantara, dr. Setiabudi (Douwes Dekker)... (4) Tahun 1914 di Semarang berdiri ISDV (Perserikatan Sosial Demokrat Hindia) oleh Sneevliet seorang pemimpin partai Sosialis dari negeri Belanda. Dengan perantaraan ISDV inilah ajaran-ajaran sosialisme (Karl Marx) mulai masuk ke Indonesia (Idris dkk., 1979: 56-57).

Dari kutipan di atas tampak bahwa antara satu fenomena historis dengan fenomena historis lainnya tidak dijelaskan keterkaitannya untuk menjadi uraian yang utuh. Dengan kata lain, Idris berusaha menampilkan setiap fenomena sebagai peristiwa yang berdiri sendiri, seperti banyak dilakukan oleh para pengarang kronik.

Berbeda dengan kedua pengarang di atas, Nugroho Notosusanto dkk. menjelaskan topik pergerakan nasional Indonesia dengan menggunakan pendekatan struktural. Pada buku teks pelajaran sejarah itu pergerakan nasional di Indonesia dijelaskan dari strukturstruktur yang membentuknya. Pada konteks yang paling besar, pergerakan nasional dijelaskannya melalui pengaruh struktur dunia, yaitu Revolusi Industri yang terjadi di Eropa pada abad ke-19 (Notosusanto, dkk., 1981, jilid 3:42). Selain itu, pengarang juga memayungi lahirnya pergerakan nasional Indonesia dengan struktur regional. Dalam hal ini, dia menggunakan perkembangan nasionalisme di kawasan Asia sebagai konteks historis bagi tumbuhnya nasionalisme Indonesia sebagai berikut.

Gejala sejarah yang terjadi itu dikenal sebagai Kebangkitan Nasional, 
yang tidak hanya disebabkan oleh faktor-faktor dari dalam negeri melainkan juga dari luar negeri. Faktor dalam negeri adalah pelaksanaan politik ethis yang dijalankan oleh pemerintah Hindia Belanda yang memungkinkan masuknya ide-ide dari Barat, maupun pengaruh pembaharuan-pembaharuan di dalam agama Islam. Faktor luar negeri antara lain adalah masuknya gagasan nasionalisme modern, khususnya pengaruh pergerakan nasional dan modernisasi di beberapa negara Asia seperti di Turki, negeri Cina dan India, serta Restorasi Meiji di Jepang dan kemenangan negeri itu atas Rusia pada tahun-tahun pertama abad ke-20, suatu kemenangan yang dianggap sebagai kemenangan orang Asia (kulit berwarna) terhadap orang Eropa (kulit putih). Karena pengaruh gagasan-gagasan modern, anggota elite nasional menyadari bahwa perjuangan untuk memajukan bangsa Indonesia harus dilakukan dengan mempergunakan organisasi modern. Baik pendidikan, perjuangan politik, perjuangan ekonomi, maupun perjuangan sosial-budaya, memerlukan organisasi (Notosusanto dkk., 1981, jilid 3: 42).

Pada kutipan di atas, Nugroho Notosusanto secara jelas menempatkan masuknya nasionalisme modern dari negeri-negeri Asia, seperti Turki, India, Cina dan Jepang menjadi unsur menentukan bagi nasionalisme Indonesia. Pengaruh itu mengakibatkan lahirnya kesadaran bahwa "perjuangan untuk memajukan bangsa Indonesia harus dilakukan dengan mempergunakan organisasi modern".

Struktur paling bawah yang digunakan untuk menjelaskan munculnya pergerakan nasional Indonesia adalah struktur kolonial. Seperti disinggung pada kutipan di atas, struktur kolonial oleh Nugroho Notosusanto ditempatkan sebagai "dalam negeri". Dia menjelaskan bahwa "faktor dalam negeri adalah pelaksanaan politik ethis yang dijalankan oleh pemerintah Hindia Belanda yang memungkinkan masuknya ide-ide dari Barat, maupun pengaruh pembaharuanpembaharuan di dalam agama Islam".

Untuk periode Kurikulum 1984, buku yang dikaji adalah Soewarso, Ibnoe, 1986, Sejarah Nasional Indonesia dan Dunia; Moedjanto dkk., 1992, Sejarah Nasional Indonesia. Jilid 3; serta Nugroho Notosusanto dkk., 1992, Sejarah Nasional Indonesia Untuk SMA. Jilid 3 (Buku Paket). Pada buku Soewarso, penyusunan lahirnya pergerakan nasional dilakukan dengan mengunakan pendekatan narratif. Pada bagian awal dibuka dengan pembahasan tentang faktorfaktor penyebab, tetapi hanya berbentuk uraian ringkas. Tidak hanya kurang mendalamnya pembahasan tentang latar belakang, pendekatan narratif juga terlihat dari pembahasan tentang organisasi-organisasi pergerakan Indonesia. Pada pembahasan tentang Budi Utomo, pengarang menguraikan sebagai berikut.

Budi Utomo adalah organisasi modern yang pertama kali didirikan oleh bangsa Indonesia. Jadi dapat dianggap sebagai organisasi pelopor/ perintis. (1) Didirikan pada tanggal 20 Mei 1908 oleh para mahasiswa Sekolah Dokter Jawa di Jakarta. Para pendirinya antara lain: Sutomo, Suraji, dan Gunawan Mangunkusumo. (2) Bersifat kedaerahan, yaitu Jawa centris. Anggotanya meliputi golong- 
an atasan yang terdiri dari kaum bangsawan dan kaum terpelajar. Jadi belum bersifat kerakyatan (Soewarso, 1986, jilid 3: 28).

Berdasarkan kutipan di atas, terlihat bahwa pengarang memberikan gambaran Budi Utomo dengan sangat singkat dan menggunakan model pointpoint.

Di pihak lain, pada buku Moedjanto, rekonstruksi lahirnya pergerakan nasional dilakukan dengan menggunakan pendekatan struktural. Pengarang menguraikan perubahan sosial yang terjadi pada masyarakat Jawa pada akhir abad XIX yang mengakibatkan terjadinya urbanisasi dan mobilitas sosial. Urbanisasi itu menjadi latar belakang yang mampu melahirkan pergerakan nasional ketika berpadu dengan migrasi antarpulau dan tumbuhnya kehidupan kota.

Kehidupan kota yang bercirikan multi-etnik semakin bernuansa ketika pemerintah kolonial mengembangkan pendidikan Barat sebagai realisasi politik Etis. Pengarang memandang pendidikan sebagai salah satu faktor utama pendorong lahirnya pergerakan nasional. Salah satu peran penting pendidikan adalah munculnya kesadaran akan terjadinya diskriminasi kolonial. Selain itu, pendidikan juga mampu melahirkan generasi baru yang berwawasan nasional, seperti diungkapkan Moedjanto (1992, jilid 2:12) di bawah ini.

Di kota-kota besar, para warga sekolah dapat secara leluasa dan langsung melakukan interaksi komunikasi dengan sesamanya. Mereka disatukan dalam pola pikir rasional dan ilmiah sehingga berbagai per- soalan dapat didiskusikan bersama. Para pelajar/mahasiswa multi etnik itu, tidak jarang saling bertukar pengalaman tentang daerah masingmasing. Dari kondisi itu, di mana pendidikan cukup besar andilnya, muncul banyak elite baru yang berwawasan nasional. Konsep tentang Indonesiasemakin populer dan mampu menggeser konsep-konsep lama yang bersifat kedaerahan, seperti konsep Jawa, Sumatera, Sunda, Borneo (Kalimantan), Celebes (Sulawesi), Ambon, dan Rote.

Dari kutipan di atas dapat diambil pemahaman bahwa kehidupan para pelajar di kota-kota pusat pendidikan Barat berhasil melahirkan elite baru yang berwawasan nasional atau sering juga disebut sebagai elite nasional.

Buku karangan Nugroho Notosusanto edisi revisi tidak memiliki banyak perbedaan dengan edisi pertama (tahun 1981). Perbedaan utama terletak pada topik sidang BPUPKI. Pada edisi pertama dijelaskan bahwa Muhammad Yamin berpidato tentang Pancasila, sedang pada edisi revisi penjelasan itu ditiadakan.

Buku teks pelajaran sejarah yang dikaji untuk Kurikulum 1994 adalah Sardiman, A.M., dkk, 1996, Sejarah Nasional dan Umum untuk SMA, jilid 2b; Badrika, I Wayan, 1997, Sejarah Nasional Indonesia dan Umum untuk SMA, jilid 2; dan Siti Waridah Q., dkk., 2000, Sejarah Nasional dan Umum untuk SMA, jilid 2. Pada buku karangan Sardiman dkk, pendekatan yang digunakan adalah deskriptif narratif. Hal itu tampak antara lain pada uraiannya tentang latar belakang munculnya pergerakan nasional yang menggunakan poin-poin (Sardiman, 
dkk., 1996, jilid 2b: 10). Seperti pengguna pendekatan deskriptif narratif pada umumnya, pengarang menggambarkan jauh lebih detil pada proses terjadinya suatu peristiwa historis. Sebagai contoh adalah ketika Sardiman (1996, jilid 2b:12-13) mendeskripsikan berdirinya Budi Utomo sebagai berikut.

Dr Wahidin Sudirohusodo, seorang pemimpin redaktur majalah Retnodumilah dan Juga lulusan Sekolah Dokter Jawa (yang sesudah tahun 1900 dinamakan STOVlA) berusaha mendorong dan memelopri berdirinya organisasi pergerakan yang bersifat modern itu. Ia berpropaganda dan berkeliling di Jawa, berusaha menghimpun bea siswa (studiefonds) untuk melaksanakan pendidikan bagi kalangan priyayi. Tahun 1907 Wahidin Sudirohusodo berkunjung ke STOVIA untuk menyampaikan gagasannya. Kunjungan ini mendapat tanggapan dan menumbuhkan semangat bagi para mahasiswa STOVIA. Salah seorang tokohnya adalah Sutomo. Kemudian, dibentuklah suatu organisasi guna memajukan kepentingan-kepenlingan kaum priyayi rendah. Oleh karena itu, pada tanggal 20 Mei 1908, hari Minggu pukul 09.00 di Aula STOVlA, Sutomo menyatakan berdirinya organisasi pergerakan yang diberi nama Budi Utomo (BU).

Badrika menyusun rekonstruksi pergerakan nasional pada buku teks menggunakan pendekatan struktural. Penggunaan pendekatan struktural tampak antara lain pada penyusunan bab dan subbab. Pengarang membagi pembahasan topik pergerakan nasional menjadi dua bab, yaitu Bab 3 yang diberi judul "Paham-paham baru yang berpengaruh terhadap pergerakan nasional Asia dan Afrika dan perjuangan kemerdekaan Indonesia" serta Bab 4 dengan judul "Pergerakan nasional". Bab 3 yang berfungsi sebagai tempat pembahasan latar belakang lahirnya pergerakan nasional Indonesia, dibagi menjadi tiga sub bab, yaitu Pengaruh paham-paham baru dari Eropa-Amerika terhadap nasionalisme di Asia-Afrika, Pertumbuhan dan perkembangan nasionalisme Asia-Afrika, Pengaruh dua perang dunia terhadap dunia internasional, khususnya kemerdekaan bangsa Asia-Afrika dan Indonesia.

Pada awal bab 4 dijelaskan pengaruh struktur kolonial terhadap kelahiran pergerakan nasional Indonesia, berupa kebijakan-kebijakan pemerintah kolonial Belanda mulai dari politik kolonial liberal. Pada uraian tentang politik Etis, Badrika (1997, jilid 2:162163) menjelaskan bahwa perkembangan kebijakan kolonial merupakan representasi perubahan pandangan, pemikiran dan kepentingan nasional negeri Belanda. Dalam konteks ini, politik Etis yang diberlakukan di Indonesia merupakan hasil dinamika historis di Negeri Belanda berupa kesadaran akan penderitaan masyarakat Hindia Belanda dan perlunya perbaikan tingkat kehidupan mereka. Salah satu aspek dari politik Etis yang oleh pengarang dipandang sangat penting adalah pendidikan.

Bidang pendidikan merupakan cita-cita yang paling penting dari perjuangan kaum penganjur Politik Etis. Bagi para pejuang Politik Etis, menyelenggarakan pendidikan di Indonesia merupakan suatu kewajiban 
moral dan tuntutan yang mendesak untuk diperhatikan secara serius.

Data-data berikut merupakan contoh kemajuan pendidikan yang diupayakan pemerintah berkat perjuangan Politik Etis. Pada tahun 1903 terdapat 1700 sekolah di seluruh Indonesia. Total jumlah murid pada saat itu adalah sekitar 190.000 orang. Sepuluh tahun kemudian (1913), jumlah sekolah di Indonesia mencapai 7000 dan total jumlah muridnya 227.000 orang. Dengan jumlah yang terus meningkat dari tahun ke tahun, perubahan-perubahan sosial yang diharapkan dari pendidikan mulai menampakkan gejala-gejala yang menggembirakan. Perubahan yang menggembirakan itu terlihat dengan pembentukan berbagai organisasi dan partai politik di Indonesia serta munculnya kaum elit baru, yakni kaum cendekiawan Indonesia yang memperhatikan nasib bangsanya (Badrika, 1997, jilid 2:166).

Pada kutipan di atas pengarang menyajikan motif, pelaksanaan dan hasil pengembangan pendidikan Barat atau persekolahan di Hindia Belanda (Indonesia). Pengarang berpendapat bahwa "pembentukan berbagai organisasi dan partai politik di Indonesia" merupakan hasil yang menggembirakan dari usaha pengembangan persekolahan yang dilakukan pemerintah kolonial. Dengan kata lain, pendidikan Barat ditempatkan sebagai rantai penyambung antara struktur lokal (masyarakat pribumi) dengan struktur-struktur di atasnya. Melalui pendidikan tersebut berhasil dilahirkan tokoh-tokoh yang dikenal sebagai elite nasional.

Hampir sama dengan Badrika, Siti Waridah dkk. juga menggunakan pen- dekatan struktural dalam menjelaskan topik pergerakan nasional Indonesia. Hal itu dapat disimak dari pembagian bab pada buku teks pelajaran sejarah yang disusunnya. Isi buku untuk jilid 2 antara lain adalah: Bab 2. Pengaruh Paham Baru dan Peristiwa Penting Dunia Internasional terhadap Perjuangan Kemerdekaan Indonesia; Bab 3: Pengaruh Perang Dunia I dan II terhadap Pergerakan Kemerdekaan di Asia Afrika; Bab 4: Pertumbuhan dan Perkembangan Pergerakan Nasional; Bab 5: Pendudukan Jepang Dalam Berbagai Aspek kehidupan Bangsa Indonesia; Bab 6: Upaya Mempersiapkan Kemerdekaan Indonesia Hingga Merdeka. Dari konstruksi bab tersebut dapat diambil pemahaman bahwa pergerakan nasional (Bab 4) ditempatkan setelah paham-paham baru (Bab 2) dan perang dunia (Bab 3) dengan maksud bahwa pergerakan nasional merupakan akibat atau hasil dari paham baru dan perang dunia.

Strukturalisme semakin terlihat dalam uraian yang dilakukan oleh pengarang ketika membahas proses kelahiran nasionalisme Eropa yang dipicu oleh ekspansi Napoleon Bonaparte. Paham bahwa kesetiaan individu diserahkan kepada negara kebangsaan itu, kemudian meluas sampai ke belahan dunia lain, termasuk ke Indonesia. Proses perjalanan nasionalisme dan pahampaham baru lainnya dari Eropa ke Indonesia tentulah dengan melalui agen yang membawanya. Dalam konteks ini, pengarang menempatkan kebijakan kolonial, yaitu politik Etis, sebagai agen perantara seperti dijelaskannya sebagai berikut.

Perkembangan paham-paham baru di Eropa dan pengaruhnya di 
Asia dan Afrika karena adanya pengaruh dari berkembangnya revolusi Prancis dan revolusi Industri di Eropa. Paham-paham baru itu misalnya liberalisme, nasionalisme, dan sosialisme.

Memasuki abad ke-20, paham nasionalisme telah masuk di Indonesia. Pelaksanaan politik etis di Indonesia telah memunculkan kaum intelektual. Pemikiran dan wawasan mereka yang semakin luas dan terbuka telah mendorong dan memperlancar berkembangnya paham baru, seperti nasionalisme. Muncullah usaha-usaha untuk memajukan dan menyempurnakan gerakan perjuangan nasional (Waridah dkk., 2000, jilid 2: 61-62).

\section{Keberagaman}

Pada Kurikulum 1975, ketiga buku yang dikaji memperlihatkan usaha untuk mewacanakan keberagaman pergerakan nasional dari berbagai perspektif. Siswoyo menekankan antara lain keberagaman dalam bidang agama dengan menggambarkan kemunculan berbagai organisasi pergerakan berbasis agama, seperti Islam, Katolik dan Kristen. Selain berbasis keagamaan, Siswoyo juga menggambarkan perkembangan organisasi berbasis kesukuan yang sering juga disebut kedaerahan dan wanita.

Hampir sama dengan Siswoyo, Idris membahas keberagaman juga dari perspektif suku atau daerah, pemuda dan wanita. Perbedaannya terletak pada ketiadaan pembahasan keberagaman organisasi pergerakan berbasis agama dalam buku teks karangan Idris. Selain itu, uraian Idris cenderung hanya menyebut nama organisasi, seperti di- lakukannya untuk organisasi berbasis suku sebagai berikut.

Organisasi-organisasi pergerakan Kebangsaan Daerah: (1) Budi Utomo. 20 Mei 1908 didirikan oleh Dr. Sutomo, di Jakarta, atas nasehat-nasehat pertimbangan dari dr. Wahidin Sudirohusodo; (2) Serikat Madura; (3) Serikat Sunda; (4) Serikat Sumatra; (5) Serikat Minahasa; (6) Serikat Ambon; (7) Kaum Betawi, dan lainlain (Idris, dkk., 1979: 56).

Hampir sama dengan Idris, Nugroho Notosusanto juga cenderung hanya menyebut berbagai nama organisasi untuk menunjukkan adanya keberagaman.

Pada periode Kurikulum 1984, buku-buku teks pelajaran sejarah juga mewacanakan keberagaman. Moedjanto menggambarkan keragaman pergerakan nasional dengan menguraikan gerakan pemuda, wanita dan bahkan militer. Pada uraiannya tentang keragaman dari perspektif militer pengarang menguraikan pembentukan Peta sebagai berikut.

Melihat kondisi yang terdesak itu kaum nasionalis merasa memiliki peluang emas mendirikan kesatuan militer untuk membela tanah air. Kesatuan militer itu tidak boleh ditugaskan di luar Indonesia. Oleh karena itu, Gatot Mangkupraja segera minta kepada pimpinan bala tentara Jepang untuk diperkenankan mendirikan kesatuan militer dan disetujui. Kemudian, pada tanggal 3 Oktober 1943 Jepang mengeluarkan "Undang-Undang" (Osamu Seirei) yang ditandatangani oleh Letnan Jenderal Harada sebagai Panglima Tentara XVI yang berkuasa atas Jawa dan 
Madura. Kesatuan baru itu diberi nama Peta, artinya Pembela Tanah Air (Moedjanto, 1992, jilid 2:73).

Dari perspektif keberagaman, buku teks karangan Ibnoe Soewarso tidak jauh berbeda dengan karangan Moedjanto, yaitu membahas keberagaman dengan menguraikan gerakan pemuda, wanita, gerakan sosial, budaya dan politik. Pada uraiannya tentang gerakan pemuda, dia menjelaskan sebagai berikut.

Organisasi Pemuda Indonesia yang pertama didirikan di Jakarta oleh Satiman Wiryosenjoyo pada tahun 1915. Organisasi itu bernama Tri Koro Darmo yang artinya Tiga tujuan utama. Anggotanya kebanyakan terdiri dari murid-murid sekolah menengah dari Jawa Tengah dan Jawa Timur (suku Jawa) (Soewarso, 1986, jilid 3:39).

Dari perspektif keberagaman, buku teks karangan Nugroho Notosusanto tidak mengalami perubahan dari edisi pertamanya. Oleh karena itu, tidak perlu dijelaskan lebih lanjut.

Pada Kurikulum 1994, Sardiman terlihat telah menunjukkan berkembangnya kebhinekaan yang terdapat pada pergerakan nasional Indonesia dari jenis organisasinya. Dia menunjukkan keragaman dalam organisasi pergerakan berbasis agama, pekerjaan (buruh), usia (pemuda) dan gender (wanita). Perspektif yang cukup menarik disampaikan oleh Sardiman (1996, jilid 2b:47) ketika menggambarkan proses berdirinya Nahdatul Ulama. Pengarang tidak terjebak pada sudut pandang saling menyalahkan dalam menggambarkan keberagaman organisasi pergerakan berbasis agama seperti pada kutipan di bawah ini.

... sikap-sikap Muhammadyah yang menentang tradisi, justru dikhawatirkan akan berakibat terlalu bebas dalam menafsirkan dan melaksanakan ajaran Islam. Hal yang demikian tidak disenangi oleh para ulama dan santri yang ada di pondok-pondok pesantren atau di daerah pedesaan. Dengan dasar pertimbangan itu maka para ulama sepakat untuk mendirikan organisasi Islam yang lain. yakni NU (Nahdatul Ulama). NU didirikan pada tangga1 31 Januari 1926 melalui pertemuan para ulama di kampung Kertopaten, Surabaya. Para ulama yang hadir dalam pertemuan itu antara lain $\mathrm{KH}$ Hasyim Asy'ari, KH. Abdul Wahab Hasbullah, KH Bisri Syamsuri. KH Mas Alwi, dan KH Ridwan.

Berbeda dengan Sardiman, Badrika lebih kaya dalam menggambarkan keberagaman pergerakan nasional, seperti pada aspek agama, pemuda, pekerjaan (buruh), daerah (kesukuan), dan gender (wanita). Pada keragaman organisasi berbasis agama, meskipun hanya membahas kaum muslim, tetapi uraiannya mencakup Muhammadiyah, Nahdatul Ulama, Al Irsyad, Sumatera Thawarid dan sebagainya. Ketika membahas organisasi kesukuan, Badrika (1996, jilid 2:231) antara lain menjelaskan sebagai berikut.

Setelah BU berdiri kemudian disusul oleh organisasi-organisasi daerah yang mencerminkan identitas dan sosio-kultural daerah. Lama-kelamaan mereka terseret oleh arus nasionalisme yang makin kuat meski- 
pun pada umumnya mereka tetap tinggal dalam organisasi sendiri.

Pada bulan September 1914, perkumpulan Pasundan didirikan di Jakarta yang bertujuan mempertinggi derajat kesopanan, kecerdasan, memperluas kesempatan kerja dan penghidupan masyarakat. Beberapa pemimpinnya ialah R. Kosasih Surakusumah, R. Otto Kusuma, dan Bupati Serang RAA Jayadiningrat yang banyak membantu organisasi itu, tetapi orang-orang terpelajar banyak yang memilih PNI Soekarno. Selain itu, Pasundan memang harus lebih dekat dengan kepentingan rakyat. Orangorang Ambon di Jawa mendirikan organisasi mereka pada tahun 1908. Dr. Tehupeiori memberikan beasiswa untuk anak-anak Ambon. Di Semarang, AJ. Patty mendirikan Sarekat Ambon yang radikal dan ingin memperjuangkan pemerintahan berparlemen.

Hampir sama dengan Badrika, Waridah juga membahas keragaman dalam pergerakan nasional dengan relatif kaya. Dia membahas berbagai organisasi pergerakan yang berbasis agama, pekerjaan (buruh), usia (pemuda) dan gender (wanita). Sebagai gambaran, salah satunya adalah uraian Waridah tentang gerakan buruh yang relatif mendetail sebagai berikut.

Gerakan kaum buruh timbul dari beberapa perkumpulan buruh Indonesia. Tujuannya adalah membela kepentingannya untuk memperoleh kesejahteraan hidup. Saat itu, nasib kaum buruh perlu mendapat perhatian karena pemerintah kolonial Belanda telah membedakan warna kulit dalam memberikan gaji, jabatan maupun status sosial. Senjata yang digunakannya adalah mogok kerja. Dengan mogok kerja mereka berharap ada perhatian dari pemerintah kolonial Belanda, atau paling tidak ada perhatian dari atasan langsung pada unit kerja masing-masing (Waridah, dkk., 2000, jilid 2: 145).

\section{Integrasi Nasional}

Dari ketiga buku teks yang diteliti, memperlihatkan gaya yang berbeda dalam mewacanakan integrasi nasional. Siswoyo menggambarkan bahwa proses integrasi nasional telah mulai mengemuka pada masa Perang Dunia I. Selain itu, dia juga menggambarkan proses terbentuknya integrasi nasional dengan menguraikan simpul-simpul peristiwa terkait. Antara lain dia mengemukakan tentang proses terbentuknya PPPKI, PBI dan Parindra, serta GAPI. Dari pergerakan wanita, Siswoyo menampilkan terbentuknya PPI (Perserikatan Perempuan Indonesia), sedang dari pergerakan pemuda ditampilkan Kongres Pemuda I dan II serta Sumpah Pemuda.

Berbeda dengan Siswoyo, Idris menggambarkan proses integrasi nasional dengan sangat singkat. Dia meninjau dua fenomena historis yang dianggapnya sebagai simpul penting terbentuknya integrasi nasional, yaitu partai politik dan pergerakan pemuda. Di pihak lain Nugroho Notosusanto dkk. memilih berbagai peristiwa yang secara umum telah dipahami dan diterima sebagai simpul-simpul terbangunnya persatuan bangsa Indonesia. Peristiwa-peristiwa itu adalah terbentuknya gabungan partai politik seperti PPPKI, GAPI dan sebagainya, kongres pemuda dan kongres wanita. 
Pada Kurikulum 1984 Nugroho Notosusanto tidak melakukan perubahan eksplanasi tentang integrasi nasional. Pada buku Moedjanto, tiga fenomena historis yang dipandang memanifestasikan proses integrasi nasional adalah pembentukan perhimpunan berbagai organisasi pergerakan, kongres pemuda dan kongres wanita. Berbeda dengan ketika menguraikan latar belakang pergerakan nasional yang cenderung detail, Moedjanto membahas simpul-simpul integrasi nasional secara singkat.

Pada Kurikulum 1994, fenomena historis yang dipandang oleh Sardiman dkk. sebagai simpul proses integrasi nasional adalah pembentukan perhimpunan antarberbagai organisasi pergerakan nasional, pemuda dan wanita. Dengan demikian, secara materi tidak memiliki fenomena historis baru yang dimunculkan. Perbedaan dengan buku teks lainnya terletak pada pemilihan kata dan penyusunan kalimat. Agak berbeda dengan Sardiman, Badrika berusaha menemukan sudut pandang lain dari proses integrasi nasional di antara berbagai organisasi pergerakan nasional. Dia menjelaskan bahwa proses integrasi pemuda melalui tahapan pembentukan PPPI dan kemudian mengadakan kongres. Dari sudut pandang ini, Sumpah Pemuda yang terjadi pada tahun 1928 dapat dipahami sebagai hasil dari sebuah proses historis yang panjang. Selain itu, Badrika berusaha menampilkan sumber primer Verslag Van Het Eerste Jong Indonesisch Conggres untuk menunjukkan tujuan dari proses integrasi pemuda.

Waridah dkk. menggambarkan integrasi dengan lebih kaya. Selain mem- bahas integrasi yang terjadi di kalangan organisasi pergerakan, pemuda dan wanita, dia juga menguraikan integrasi yang terjadi di kalangan organisasi pergerakan berbasis agama Islam. Dalam konteks ini, dia menjelaskan berdirinya MIAI pada tanggal 21 September 1937.

\section{EVALUASI}

Dari dua pendekatan yang digunakan oleh para pengarang buku teks menunjukkan bahwa pendekatan struktural lebih mampu memenuhi kriteria yang diberikan Sartono Kartodirdjo. Dari dua unsur yang digunakan untuk aspek pendekatan, uraian buku teks dengan menggunakan pendekatan struktural mampu menjelaskan faktor atau kekuatan yang memengaruhi lahirnya pergerakan nasional, baik ekonomi, sosial, politik maupun kultural, meskipun belum optimal. Ketidakoptimalan terutama pada uraian faktor-faktor kekuatan global yang melatarbelakangi lahirnya pergerakan nasional Indonesia yang tidak sebaik penjelasan pada faktor-faktor kekuatan lokal.

Selain kurang optimal, semua buku teks gagal untuk mengungkapkan "sejarah dari dalam". Tidak satu pun buku teks, baik yang menggunakan pendekatan deskriptuf narratif maupun struktural, berusaha menggali kebudayaan lokal sebagai habitus bagi lahirnya nasionalisme Indonesia. Struktur lokal, yaitu kondisi sosio-kultural tempat para pelaku sejarah pergerakan nasional dilahirkan dan dibesarkan, cenderung diabaikan atau dipandang sebagai unsur yang tidak memiliki relevansi tinggi untuk dibahas dalam rekonstruk- 
si sejarah nasionalisme Indonesia. Para pengarang buku teks justru menggunakan ideologi yang berkembang di Barat dan berbagai ebijakan pemerintah kolonial sebagai kekuatan yang memengaruhi/mendorong lahirnya nasionalisme Indonesia. Akibatnya, fenomena historis muncul dan berkembangnya nasionalisme bukan dipandang sebagai representasi pelaku sejarah dengan seluruh konstruk mentalnya. Sebaliknya, peristiwa itu lebih dipandang sebagai akibat tak terduga (unintended result) dari inovasi Barat, khususnya kolonialisme Belanda.

Dua karakteristik yang paling menonjol diuraikan oleh pengarang buku teks ketika membahas keberagaman adalah ragam organisasi dan pribumi. Penekanan pada ragam organisasi tingkat nasional terdapat dalam uraian tentang organisasi sosial, politik, keagamaan, wanita dan pemuda/pelajar. Hampir seluruh organisasi yang dibahas merupakan organisasi yang didirikan dan dikembangkan oleh pribumi. Satu-satunya pembahasan organisasi yang memiliki anggota nonpribumi adalah Indische Partij. Hal itu pun dijelaskan oleh banyak pengarang dengan tidak mengaitkannya pada etnik Indo Belanda. Etnik nonpribumi lain, seperti Tionghoa dan Hadrami sama sekali tidak dibahas. Peniadaan gerakan etnik nonpribumi bertentangan dengan realitas historis karena etnik Tionghoa telah mendirikan Tiong Hoa Hwee Koan (THHK) pada tahun 1900 (Onghokam, 2009) dan etnik Hadrami mendirikan Jam'iyyat alKhayr pada tahun 1901 (Jacobsen, 2009).

Selain meminggirkan etnik nonpribumi, buku teks pelajaran sejarah juga lebih banyak membahas dinamika historis yang terjadi di Jawa. Sebenarnya setiap organisasi pergerakan memiliki cabang di berbagai wilayah sehingga sangat terbuka luas untuk dibahas dan menggambarkan keberagaman dengan lebih kaya. Ketidakbersediaan pengarangmenjadikanuraian buku teks memberi kesan hanya membahas sejarah Jawa.

Secara teoretis, integrasi nasional mengandung dua unsur utama, yaitu integrasi vertikal yang berkait dengan hubungan antara elite dengan massa rakyat serta integrasi horisontal yang terkait dengan dinamika sosiokultural daerah dan penciptaan hubungan yang kohesif dengan daerah-daerah lain secara nasional. Dari sudut pandang ini, para pengarang buku teks lebih banyak menjelaskan integrasi vertikal, tetapi sangat kurang memberikan ruang untuk integrasi horisontal. Para pengarang tidak membahas etnonasionalisme yang berkembang pada berbagai etnik. Bahkan mereka mengategorikan berbagai fenomena etnonasionalisme ke dalam pergerakan nasional, seperti terjadi pada pembahasan Budi Utomo, Serikat Minahasa, Jong Ambon dan sebagainya. Akibatnya, dinamika terbentuknya integrasi nasional yang terikonkan dalam "Bhineka Tunggal Ika" tidak dapat terkemukakan dengan baik. Selain itu, kategorisasi ke dalam pergerakan nasional juga bertentangan dengan realitas historis. Purwanto (2006: 182) mengemukakan bahwa proses pembentukan identitas keindonesiaan berjalan seiring dengan identitas etnik. Dua-duanya mengalami proses transformasi secara sinergis membentuk 
identitas masing-masing tanpa harus saling bertentangan.

\section{PENUTUP}

Dari analisis terhadap isi buku teks pelajaran sejarah dapat disimpulkan bahwa penggunaan pendekatan struktural telah mampu menjelaskan faktorfaktor yang memengaruhi terjadinya pergerakan nasional, tetapi belum mampu mengungkapkan sejarah dari dalam. Uraian buku teks didominasi oleh penjelasan tentang faktor luar, baik kolonialisme Belanda, nasionalisme Asia dan ideologi Barat. Pada aspek keberagaman, kekurangan utamanya adalah pada narasi tentang etnik nonpribumi dan dinamika historis pergerakan nasional di berbagai daerah luar Jawa. Kekurangan itu menjadikan uraian buku teks bersifat jawa sentris dan pribumi sentris.

Pada aspek integrasi nasional, buku teks didominasi oleh uraian tentang integrasi vertikal dan sangat kurang pada pembahasan integrasi horisontal. Akibatnya, realitas sosiokultural bahwa identitas nasional dan identitas lokal (etnik) berjalan beriringan tidak dapat tergambarkan dengan optimal. Bahkan uraian buku teks memberi kesan bahwa identitas nasional berkembang dengan mematikan identitas lokal.

\section{UCAPAN TERIMAKASIH}

Ucapan terima kasih disampaikan kepada berbagai pihak yang telah memungkinkan membantu pelaksanaan penelitian ini.
DAFTAR PUSTAKA

Ankersemit F.R. 1987. Refleksi Tentang Sejarah: Pendapat-Pendapat tentang Filsafat Sejarah. Diterjemahkan oleh Dick Hartoko. Jakarta: Gramedia.

Ansary, Hasan and Esmat Babaii. 2002. “Universal Characteristics of EFL/ ESL Textbooks: A Step Towards Systematic Textbook Evaluation". The Internet TESL Journal, Vol. VIII, No. 2, February 2002. http:itteslj.org/Articles/Ansary-Textbooks/. Diunduh pada tanggal 2 Oktober 2010.

Ileto, Reynaldo C. 2002. "On the Historiography of Southeast Asia and the Philippines: The 'Golden Age' of Southeast Asian Studies Experiences and Reflections". Proceedings of the Workshop on "Can We Write History?" Between Postmodernism and Coarse Nationalism" (Institute for International Studies, Meiji Gakuin University, 9 March 2002).

Jacobsen, Frode F. 2009. Hadrami Arabs in Present-day Indonesia: An Indonesia-oriented group with an Arab signature. London: Routledge.

Mulyana, Agus dan Darmiasti. 2009. Historiografi di Indonesia. Bandung: Refika Aditama.

Nagazumi, Akira. 1968. Toward An Autonomous History of Indonesia. http://onlinelibrary.wiley.com/doi/10. 
1111/deve.1968.6.issue-2/issuetoc, Purwanto, Bambang dan Adam, Asvi diunduh pada 25 Februari 2012.

Onghokam. 2009. Riwayat Peranakan

Tionghoa di Jawa. Jakarta: Komunitas Bambu.

Warman. 2005. Menggugat Historiografi Indonesia. Yogyakarta: Ombak.

Purwanto, Bambang. 2006. Gagalnya Historiografi Indonesia?! Yogyakarta: Ombak.

Peraturan Menteri Pendidikan Nasional (Permendiknas) No. 11 Tahun 2005.

Said, Edward. 1977. Orientalism. London: Penguin. 